\title{
Multiculturalism and Narratives of Belonging: Tracing the Intersection of Chilean Migration and Hip-hop Culture in Sweden
}

\section{Susan Lindholm}

\begin{abstract}
This article focuses on what will be called narratives of belonging created through hip-hop culture by the children of Chilean refugees who came to Sweden during the 1970s and 1980s. Chile is especially interesting in this context, as Sweden accepted the largest number of Chilean political refugees in Europe after the 1973 military coup. The article argues that the work of Swedish hip-hop artists who actively address a Chilean background through their work can be read as narratives of belonging in a number of different ways. This specific negotiation of a Chilean identity becomes intelligible as a narrative of belonging in Sweden against the background of othering and segregation processes, and a form of multiculturalism that affirms both difference and equality. It creates belonging as a reaction to othering processes that are visible in both the persisting segregation in housing and labour markets along ethnic and racial lines, as well as the election of the Sweden Democrats, a right-wing, anti-immigration party into the Swedish national parliament in 2010,2014 , and most recently in 2018. It also creates belonging in the context of a multiculturalism debate that stresses difference as desirable, that is, as a means of inclusion into mainstream society. The article argues that, if being different means being part of a group, individuals will set out to define their specific difference, in this case by creating narratives of belonging that connect them to a specific (idealized) version of a Swedish past, in order to define their membership within that group.
\end{abstract}

Keywords: Multiculturism, Sweden, refugees, belonging, migration 


\section{Susan Lindholm}

\section{Introduction}

In many European countries, the concept of multiculturalism emerged as a reaction to non-white immigration, specifically from outside Europe (Modood 2013: 2). As such, it has been used as means to affirm the existence and equal value of different cultural groups, and thereby also to affirm these group's claims to (national) belonging. In Sweden, multiculturalism became an important element of welfare-state politics in the mid-1970s, when it was implemented as a strategy to prevent ethnic conflicts and cultural segregation (Ålund \& Schierup 1990:2; Modood 2013: 3; Hübinette \& Lundström 2014: 429). Today, Sweden is internationally acknowledged for having the most thorough anti-discrimination legislation, and a population that predominantly identifies as anti-racist. Yet, contrary to initial intentions, Sweden has also developed into one of the most statistically segregated and segmented societies in regard to housing and labour, with immigrants from non-Western countries having significantly lower income and being more likely to live in low-income areas than Swedes without such a migration background (Regeringskansliet 2011). This problem is further intensified, as there is growing evidence that these patterns of segregation seem to be 'inherited' by the Swedish-born children of non-Western migrants (Hübinette \& Lundström 2014: 424).

In this article, I discuss what will be called narratives of belonging created through hip-hop culture by the children of Chilean refugees who came to Sweden during the 1970s and 1980s. Chile is especially interesting in this context, as political refugees who fled the country after the 1973 military coup were warmly welcomed in Sweden, the country that accepted the largest number of Chilean refugees in Europe (Tornbjer 2008). While earlier research on the children of these refugees has both shown an increasing and decreasing identification with Chile, I here focus on the work of Swedish hip-hop artists who actively address a Chilean past in interviews, videos and TV shows (Olsson 2007: 220; Esquivel Sánchez 2005: 78). Hip-hop, in turn, has been described as a cultural form which 'gives voice' to marginalized cultural identities by making them visible and audible in mainstream media (Sernhede \& Söderman 2010). The article will specifically focus on the question in what way the work of Swedish hip-hop artists who actively address their Chilean background can be read as narratives of belonging in the context of a form of multiculturalism that affirms both difference and equality. The analysis falls in four parts. A first part that focuses on the development of hip-hop culture in Sweden during the 1990s, a second part that analyses song lyrics as narratives 
of belonging, a third part that discusses the construction of a Chilean identity during an interview, and finally, a fourth part that focuses on the way in which a Chilean past is discussed in a Swedish TV programme.

\section{Multiculturalism, Solidarity with Chile, and Hip-hop Culture in Sweden}

During the 1930s, a political compromise between the Social Democratic Party and the Farmer's League led to the creation of a Swedish model of welfare politics that was designed to abolish 'all social and economic barriers' by implementing an array of social security reforms (Bade 2003: 256; Byström \& Frohnert 2013: 7). Immigrants, who started to arrive in Sweden in greater numbers in the post-war period, were later also included in this version of the welfare state (Byström \& Frohnert 2013: 12). Sweden soon became 'the first to move in the direction of becoming a formal immigration country' (Bade 2003: 256). The Swedish brand of multiculturalism that was designed as a reaction to such immigration in the 1970s provided formal equality before the law, and access to unemployment contributions and other social welfare benefits. It was based on a moral and political consensus in the 1970s that advocated respect for immigrant culture and advocated the freedom of choice to either assume a Swedish cultural identity, or to retain and develop a different cultural identity. It also emphasized the premise that all cultural identities are equal, and that they should benefit from working together (Ålund \& Schierup 1991: 2). As noted above, the aim of this brand of multiculturalism was to prevent ethnic conflicts and the development of a segregated society.

This Swedish brand of multiculturalism also combined providing immigrants and ethnic minorities with resources to exercise political influence on the domestic front with international solidarity at the level of foreign politics (Ålund \& Schierup 1991: 2; Thörn 2002: 96, 108; Tornbjer 2008: 60). Such international solidarity was especially accentuated after the 1973 military coup in Chile, as large numbers of Chileans who sought refuge in Sweden after the coup were not only warmly welcomed by the Swedish government under prime minister Olof Palme, but also by a large number of civilian groups such as the Chilekommitén, the Chile committee (Christiaens et al. 2014: 10; Gradskova n.d.: 15). While Sweden was by no means the only country where Chileans took refuge, it quickly became the country that welcomed the highest number 


\section{Susan Lindholm}

of Chilean refugees in Europe ${ }^{1}$. During the period of the Pinochet regime, both the Swedish solidarity movement and the Chilean exile community focused on opposing the Pinochet regime through political and cultural activism (Lindqvist 1991; Olsson 2007; Tornbjer 2008). As democratic rule was reinstated in Chile in 1990 however, the Chilean post-exile community had to find new strategies for group mobilization, as the political resistance against the Pinochet regime no longer served to unite the very heterogeneous group (Lindqvist 1991:34).

The post-exile period also made internal divisions more visible. Erik Olsson argues that the children of these Chilean refugees no longer automatically identified themselves with Chile, while María Denis Esquivel Sánchez refers to a study that states that the children of Chilean refugees have started to identify themselves with Chile to a greater extent than their parent generation (Olsson 2007: 220; Esquivel Sánchez 2005: 78). Some of the issues that replaced opposing the Pinochet regime in the negotiation of a Chilean group identity in Sweden after 1990 were discrimination and marginalization based on ethnic categories. These are the exact same issues that earlier research has pointed out as central issues within Swedish hip-hop that emerged during the 1980s and 1990s (Sernhede \& Söderman 2010). Swedish hip-hop has mainly been studied as a collective culture that has united youth in the suburbs (förorten) with a wide variety of immigration backgrounds behind the common goal of challenging social hierarchies that create economic and racialized marginalization. However, instances in which hip-hop artists create narratives of belonging in connection to different pasts and cultural identities have not been the focus of previous Swedish research. By discussing the way in which hip-hop artists create narratives of belonging through their work, I argue that hip-hop is a cultural form that fits well into what Magnus Nilsson calls the idea of Sweden as a multicultural society (Nilsson 2008: 271).

Yet, the early 1990s also saw a backlash against immigration and multiculturalism, which became visible in the political sphere in 1991, as $N y$ Demokrati (New Democracy) was elected into the Swedish national parliament on an anti-immigration platform. The elections took place against the background of an economic downturn, and the increasing arrival of nonWestern migrants in Sweden in the late 1980s and early 1990s. Yet, while $N y$

\footnotetext{
${ }^{1}$ For a discussion of European solidarity towards Chile after 1973 see for instance: Christiaens et al. (eds.) (2014).
} 
Demokrati was unable to gain seats in the following elections, Sverigedemokraterna (the Sweden Democrats), another right-wing party that ran on an anti-immigration platform entered the Swedish parliament in both the 2010 and the 2014 elections. In 2010, the party gained almost 6 percent of the vote and 20 elected representatives. Since the 2014 elections, it has been the third largest party in the Swedish national parliament holding 12,9 percent of the vote. After both elections, the Swedish cultural establishment was outspokenly critical of the party's anti-immigration platform that is based on the assumption that cultural identities are essential and inherited, and that multiculturalism cannot work in practice, as not all cultures are compatible with each other (Hübinette \& Lundström 2014: 424). In the following, I will discuss my material, and the way in which I use the concept of narratives of belonging in my analysis of the work of Swedish hip-hop artists who actively create a Chilean, that is, at first glance non-Swedish, cultural identity through their work.

\section{Narratives of Belonging in Hip-hop Culture}

My analysis is based on interviews with two hip-hop artists, song lyrics, a video, and a TV programme. I conducted the first interview with Cristian Salla Salazar Campos, a former member of the seminal group The Latin Kings, as well as a co-founder of the record label Redline Recordings, and the production company The Salazar Brothers, in July 2015. Salla's parents were among those Chileans who came to Sweden in the late 1970s. I also conducted an interview with hip-hop artist, producer and activist Rodrigo Rodde Bernal in November 2013. Rodde is a member of the group Hermanos Bernal, a hip-hop group that consists of him and his brother Cristian Bernal. He was born in Chile and came to Sweden with his family as a child. The interview with Salla was conducted at the Red Line Studios in Norsborg, Stockholm in July 2015, and the interview with Rodde was conducted at the local ABF in Kalmar in November 2013. Both interviews were semi-structured and conducted in Swedish. The initial question on which they were based was why there are so many artists and producers with a Chilean background in Swedish hip-hop.

My analysis is also based on the lyrics, music and visual narrative of the joint video 'Ett land som är tryggt'/ 'Betongbarn' (A country that is safe/ children of the concrete) by the Malmö-based group Advance Patrol. The group consists of rappers Juan Havana (Juan Hektor Paez Larraguibel), Gonza 


\section{Susan Lindholm}

(Gonzalo Rodrigo del Rio Saldias) and D.J. Lucutz (Lucas Simon Alsén). Both Juan's and Gonza's parents emigrated from Chile to Sweden during the 1970s and 1980s. Finally, I also discuss an episode of the Swedish TV programme 'Lyckliga gatan' (the happy street) that features The Salazar Brothers as producers. Both the video and the TV programme are accessible on the video platform YouTube.

I have listened to the two songs, watched the videos, and read a written form of the song lyrics available on a homepage dedicated to Swedish hiphop $^{2}$. After having repeatedly listened to and watched my material, I noted those instances in which a Chilean past becomes most prominent, and picked a few of these instances to be discussed in this article. All translations from Swedish included in this article are my own.

In the following, I analyse this material in terms of what I will call narratives of belonging that are created within the framework of a multiculturalism debate that stresses both difference and equality. Based on the premise that all cultural identities are constantly changing, as they are created and negotiated through an interplay between historical and social structures and individual agency, I discuss the way in which these artists create belonging and negotiate a Chilean identity through hip-hop in Sweden (Brah et al. 2009: 73). I thus focus on the intersection of hip-hop culture and migration rather than tracing the constructions of personal history through hip-hop. As Chris Weedon points out, cultural narratives and practices can offer new forms of identity and agency, as they contribute to and become part of processes that negotiate culturally dominant forms of identity (Weedon 2004: 61). Identities are here in other words seen as socially constructed and negotiated, with individuals actively engaging in identity work by drawing on and creating narratives of belonging.

Thus, the following analysis discusses the way in which the work of the above-named hip-hop artists can be read as narratives of belonging in the context of a form of multiculturalism that affirms both difference and equality. It falls in four parts. The first part exemplifies the work of The Latin Kings in relation to hip-hop as an emerging music genre in Sweden during the 1990s. In the second section I discuss the joint video 'Ett land som är tryggt'/ 'Betongbarn' by the group Advance Patrol as an example of a narrative of belonging in Sweden, while the third section focuses on the way in which

\footnotetext{
${ }^{2}$ http://hiphoptexter.com/
} 
Rodde created a Chilean identity during our interview. In a fourth and final section I discuss an episode of the TV program 'Lyckliga gatan' in order to outline the continuing importance of a Chilean past for creating a narrative of belonging through Swedish hip-hop today.

\section{The Latin Kings/ Los Reyes Latinos: Swedish Hip-hop in the 1990s}

This first section is mainly based on the interview that I conducted with Cristian Salla Salazar Campos in June 2015. As pointed out above, hip-hop in Sweden has mainly been studied as a collective culture that has united youth in the suburbs (förorten) with a wide variety of immigration backgrounds behind the common goal of challenging social hierarchies that create economic and racialized marginalization. The areas that are today known as the förorten are low-income areas that are mainly, but not exclusively, located outside of the city centers of the three largest Swedish cities Stockholm, Gothenburg and Malmö (Sernhede \& Söderman 2010). These areas became the marker of a segregated city along the lines of class, ethnicity, and race in the 1990s, and are therefore often compared with inner-city neighbourhoods in the United States (Lilja 1999: 101; Sernhede 2007). While the förorten was often described as problematic even before the emergence of hip-hop in Sweden, the culture quickly became the representative of these problems in the public debate in the 1990s (Ristilammi 1994; Ericsson et al. 2002; Sernhede \& Söderman 2010:3). Consequently, the importance of earlier personal or familial migration experiences expressed within Swedish hip hop has not been the focus of previous research.

In the mid -1990s, the group The Latin Kings was credited for having made audible and visible these förorten in Swedish mainstream media. The Latin Kings consisted of the brothers Cristian Salla and Hugo Chepe Salazar Campos whose parents were among those Chileans who migrated to Sweden in the late 1970s, and their friend, Douglas Dogge Doggelito León. The group released their successful debut album Välkommen till förorten (Welcome to the förorten) in 1994. As literary scholar Magnus Nilsson points out, their debut album also ignited hope among the middle class that Sweden would soon also witness the emergence of a form of migrant literature (invandrarlitteratur) that would represent a multicultural Swedish society (Nilsson 2008: 271). The 
emergence of hip-hop culture was thus closely tied to a political debate on multiculturalism in Sweden during the 1990s.

In 1996, The Latin Kings also released a Spanish version of their debut album called Bienvenido a mi barrio (Welcome to My Neighborhood) under the name Los Reyes Latinos. Almost all lyrics on that album are directly translated from Swedish to Spanish, with the notable exception of those passages that address the situation that Swedish youth face in the förorten. One of the songs featured on the Spanish version of that album that was not included in the Swedish version was called Latinos somos (We Are Latinos), and became a hit in Latin America. It was featured on MTV Latino and The Latin Kings travelled to New York, Miami and Mexico to promote it. However, although they mention their Chilean background in the lyrics of that song, Salla argued that The Latin Kings did not specifically intend to launch their music in Chile during our interview. Their music was thus more directed at a Swedish or UScontext rather than a Chilean or Latin American context.

As pointed out by earlier research, the work of The Latin Kings and other hip-hop artists in the 1990s mainly served to make visible the förorten in Swedish media during the 1980s and 1990s (Sernhede \& Söderman 2010). These artists thus used the culture in order to make visible the experiences of marginalized youth in mainstream culture, an attempt that can be discussed in terms of a claim to, and thereby a narrative of, belonging that fits well into the framework of multiculturalism that stresses both difference and equality. Yet, as hip-hop was associated with the förorten, it not only made visible, but also stressed the idea that the cultural other in a multicultural society was located in such low-income areas. During our interview in 2015, Salla specifically stressed that the group resisted being reduced to representing the förorten in their on-going work. It also becomes clear in this first section that defining a Chilean identity was not a central aspect for The Latin Kings during the 1990s. However, such attempts started to surface in the 2000s in the work of groups such as Advance Patrol that I will discuss in the following section.

\section{Advance Patrol: Remembering a Country that is Safe}

In this second section, I focus on the first part of the lyrics and the joint video of the songs 'Ett land som är tryggt'/ 'Betongbarn' (a country that is safe/ children of the concrete) that was published in 2005 by the Malmö-based group Advance Patrol. The group consists of rappers Juan Havana (Juan Hektor Paez 
Larraguibel), Gonza (Gonzalo Rodrigo del Rio Saldias) and D.J. Lucutz (Lucas Simon Alsén). Chafic Mourtada, an earlier member of the group died in 2002. Both Juan's and Gonza's parents emigrated from Chile to Sweden during the 1970s and 1980s. The production company The Salazar Brothers that was created by the two former members of The Latin Kings Cristian Salla and Hugo Chepe, and their third brother Marcelo Masse Salazar Campos, produced several songs featured on Advance Patrol's four full-length albums released between 2003 and 2009. While The Latin Kings did not explicitly direct their music at Chile, Advance Patrol produced a Spanish album in cooperation with Cesar Cestar Morales from the Chilean group Shamanes Crew and went on tour in Chile in 2008.

The first part of the video 'Ett land som är tryggt'/ 'Betongbarn' (a country that is safe/ children of the concrete) addresses the flight of their parent's generation from Chile to Sweden in the 1970s. In includes the following lines rapped by Juan:

När Olof var boss, sträcktes handen mot oss

Palme gav oss skydd, ett jobb, ett ställe att bo på.

Kan inte glo på, vi har att göra.

Inte för vår skull utan för dom döda

30 år har gått och dom minns tillbaks.

Dom var yngre än mig och lämna allting kvar.

Mina föräldrar bland hundratusentals par utspridda över hela världen med sina barn.

Jag ska bli president nån dag.
When Olof was the boss, a hand reached out to us

Palme protected us, gave us a job, a place to live.

I cannot just stand and stare, we have things to do,

Not for our sake but for the dead,

Thirty years have passed and they remember,

They were younger than I am now and they left everything behind.

My parents among hundred thousand couples,

Spread over the entire world with their children.

I will become president some day. 


\begin{tabular}{|l|l|}
\hline $\begin{array}{l}\text { Låta en viss general få ta sitt } \\
\text { ansvar. }\end{array}$ & $\begin{array}{l}\text { Let a certain general take his } \\
\text { responsibility. }\end{array}$ \\
$\begin{array}{l}\text { Min mamma säger Juan du har } \\
\text { egna strider }\end{array}$ & $\begin{array}{l}\text { My mother says Juan you have } \\
\text { your own fights }\end{array}$ \\
din kamp är när du berättar och & Your fight is when you narrate \\
skriver. & and write. \\
Vill inte låta allt för naiv men jag & Do not want to sound too naïve \\
är aktiv & but I am active \\
klarar inte av att stå bredvid. & Cannot cope to simply stand \\
& aside. \\
Vill kunna mer om politik och & Want to know more about \\
skriva & politics and write \\
om många människors liv, & About many people's lives, \\
förtryck och krig & oppression and war. \\
& \\
\hline
\end{tabular}

(Advance Patrol, 'Ett land som är tryggt'/ 'A country that is safe')

In this excerpt, Advance Patrol create a clear connection between the political fight of their parents who fled from Chile to Sweden during the 1970s when Olof Palme was the Swedish prime minister, and their own political activism as hip hop artists. Yet, although Juan mentions Pinochet ('let a certain general take his responsibility'), who was still alive as the video was released, he places his activism in the present. He has his 'own fights' that consist of addressing current 'oppression and war' as a hip-hop artist. The visual narrative of the video further stresses such a connection. The video displays captions of newspapers, black and white film clips showing soldiers driving, walking, standing or shooting guns in the air, as well as groups of people demonstrating (0:04), as well as family photographs that display individuals parents and children - who are smiling or seem relaxed, dressed in 1970s' clothing (0:33). Yet, as both the lyrics and the newspaper captions are all in Swedish, the video is clearly directed at a Swedish audience.

As the first part of the video is nearing its end Gonza starts rapping. He dedicates the song to different areas in Malmö that have been perceived and defined as förorten by the mainstream media starting in the 1990s: Rosengård, Lindängen, Sofielund, and Kroksbäck. Gonza calls on all the inhabitants of these areas to raise their hands and to sing the 'allsången'. The 'allsången', 
roughly translated as 'singalong' or 'song of all', is a popular phenomenon in Sweden, with a TV programme called 'Allsång på Skansen' devoted to it during the summer months. Gonza's reference to it can therefore be seen as a means to include the marginalized voices from the förorten into mainstream culture. Before starting to address the situation that youth living in these areas find themselves, Gonza stresses the importance of his message by rapping: 'this is important, this is real, this is what happens in my district'. He continues with the following lines:

För vi e dumma, vi e skumma

Vi e ungdomar som flummar Aggressivitet i vår personlighet Problemet är att vi inte hittar vår identitet

Glamorösa drömmar är seriösa Jag är uppväxt med föräldrar som är långtidsarbetslösa

Så pass, vilken underklass Att jag trampar fel oavsett vilket slags kompass

Jag blir så trött på att bli dåligt bemött

Så jag blandar upp en fet holk För att mitt hopp har dött
Because we are stupid, we are suspicious

We are youth who are high

Aggressiveness is our personality

The problem is that we do not find our identity

Glamorous dreams are serious I grew up with parents who are long-term unemployed

Like that, what underclass

That I make the wrong moves no matter what kind of compass

I am so tired of being treated badly

So I roll a fat joint

Because my hope has died

(Advance Patrol, 'Betongbarn'/ children of the concrete)

The tone used in these lyrics stands in stark contrast to the tone used in the first video. Gonza states that he has grown up with parents who were long-term unemployed, and that he had to sell drugs to make a living. Whereas 'Ett land som är tryggt' clearly refers to a specific version of a past between Sweden and Chile, Gonza here states that his, and other youths' problem is that they cannot find an identity. The visual narrative of the video further stresses this contrast. The images that are displayed consist of black and white film 


\section{Susan Lindholm}

clips and images that show male youth standing in groups - in front of a brick wall, in front of high-rises, and in the streets (1:57). The video ends with a block party in the förorten: children are playing with a small remote-controlled toy police car, and a group of young girls in white t-shirts and black sweatpants dance to the Arabic tune (3:33). In the refrain, Juan raps that they, the 'children of the concrete' are now 'continuing to tie the ties of blood' (Betongbarn, knyter vidare på blodsbandet). That means that Advance Patrol here define those who live in the förorten as their extended family. Solidarity and a Chilean identity based on solidarity, is thereby extended to all marginalized youth living in the förorten.

In this video, the group Advance Patrol thus not only sets out to make visible the experiences of marginalized youth who grew up in the förorten, they also stress a specific past between Chile and Sweden that they connect to their activism as hip-hop artists. Thereby, they create a narrative of belonging that is based on a specific version of the past that is marked by solidarity between Chile and Sweden during the 1970s and 1980s. As both the lyrics and the visual narrative of the video are in Swedish, this narrative is clearly directed at a Swedish, rather than a Chilean context. Thereby, Advance Patrol highlight a specific Chilean identity in a Swedish context that is defined as different, while at the same time, it is narrated as part of a Swedish past. By combining this version of the past with the group's experience of growing up in the förorten, the video thus sets out to remind Swedish society of a time that was marked by solidarity towards migrants, rather than segregation along racial lines. In the following, I will further discuss the definition of such a Chilean identity in greater detail, based on an interview that I conducted with hip-hop artists Rodrigo Rodde Bernal.

\section{Rodrigo Rodde Bernal: Being Chilean as Being Cultural}

Rodrigo Rodde Bernal's family came to Sweden in 1986, when he was three years old, yet they returned to Chile when he was fourteen to then once more move back to Sweden when he was eighteen. As mentioned above, Rodde is a member of the group Hermanos Bernal, that is, the Brothers Bernal, a hip-hop group that consists of him and his brother Cristian Bernal. In addition to rapping he also works in different hip-hop projects with marginalized youth through his project Ung Aktiv (Young Active). While Hermanos Bernal are today mainly rapping in Spanish, they also used to rap in Swedish before being 
'discovered' by Marcelo Masse Salazar Campos from the production company Salazar Brothers. After recording a few songs in Spanish on their own, they started to work with The Salazar Brothers who produced their first Spanish album called 'Directo de Suecia' (Direct from Sweden) in 2008. Just as Advance Patrol, Hermanos Bernal also went on tour in Chile with that album. By the time of our interview, the right-wing party the Sweden democrats had been sitting in the national parliament for three years, having gained almost 6 percent of the vote and 20 elected representatives in the 2010 elections.

During our interview, Rodde repeatedly returned to the question, why there are so many Chileans who work in the Swedish music industry as rappers, organizers, bookers, and sound and light technicians. He ended up explaining that, in his view, Chileans, in general, are 'cultural' as, 'whenever there is something cultural that is being organized you can bet on finding at least one Chilean involved in it'. When I asked him to define what he meant by the term cultural, he explained that he was referring to entertainment. Following such logic, becoming a Chilean Hip-hop artist, therefore, simply means becoming that which one already is by virtue of being Chilean, namely cultural. As Erik Olsson points out, such an image, that is, the myth of the intellectual, expressive Latin American migrant engaged in a cultural lifestyle, was created during the exile period in Sweden that lasted until the reinstatement of democratic rule in Chile in 1990 (Olsson 2007: 224).

It also became apparent that Rodde's definition of a Chilean identity as 'cultural' only works in a Swedish context. As becomes evident through the title of their album 'Directo de Suecia' (Direct from Sweden), Hermanos Bernal actively describe themselves as Swedish in Chile. During our interview, Rodde nevertheless repeatedly stressed the importance of performing raps in 'correct Chilean Spanish' since, as a musician 'you represent Chile,' which is why you must avoid 'sounding like a tourist'. Such restrictions nevertheless only apply to a musical context, as Rodde had earlier described Chile as an open society in which everyone is welcome, even those who can only say hola, that is, hello in Spanish. When I confronted him with this contradiction, he agreed by stating: 'Yes! It is contradictory! And every time I ask them: but you said it was this way, and now you say it's the other way. They say: that's how it is'. Although he did not explain to me what exactly he meant by it, I here take it as referring to culture. Rodde does in other words not have any problems defining Chileans as cultural in a Swedish context. Yet, such a definition becomes more difficult or outright impossible in Chile, where he receives con- 


\section{Susan Lindholm}

flicting answers to his questions as he tries to define Chilean culture.

As the image of the 'cultural' Latin American or Chilean migrant was created during the Chilean exile period, it can be argued that Rodde here draws on an already available image of being Chilean in Sweden, an image that fits well into a general debate on multiculturalism in Sweden that accentuates cultural difference as desirable. His definition of a Chilean identity through hip-hop thus also becomes a narrative of belonging that is directed at a Swedish context. During our interview Rodde added various reasons why he set out to create such an identity as a hip-hop artists. These reasons included the influence of the pioneering group The Latin Kings, the memberos of which became his role models in the 1990s, as well as his family's background and his own childhood in Chile. However, the main reason why the work of The Latin Kings had such an impact on him was that it highlighted his specific difference as positive. Rodde repeatedly stressed that, while growing up in Sweden, he had always been identified as different, and that The Latin Kings defined a specific Chilean or Latino identity as desirable in Swedish mainstream media. In the following section, I will discuss the way in which The Salazar Brothers, the production company that was founded by Salla and Hugo, two former members of The Latin Kings, and their third brother Masse highlight the importance of remembering a Chilean past in a current TV programme.

\section{The Salazar Brothers: Remembering Chile}

As mentioned above, while The Latin Kings never went on tour in Chile, the production company The Salazar Brothers that was created by Salla, Hugo and Masse started to produce musicians such as Advance Patrol and Hermanos Bernal from the 2000s onward. Yet, while they also produced other hip-hop artists from Chile such as Zaturno and Sole, as well as other Swedish hip-hop artists with a Chilean background, they neither limit themselves to producing Chilean or Latin-American artists not necessarily to hip-hop as a genre. In this fourth and final section I will nevertheless discuss the continuing importance that The Salazar Brothers assign to a specific aspect of a Chilean past in their work. This past concerns the cooperation between Chilean nueva canción musicians who had been supporting Salvador Allende's presidency and the Swedish proggrörelsen.

Many of the exiled nueva canción musicians and writers who had been able to flee the country after 1973 visited Sweden during the 1970 s and 1980s 
where they were warmly welcomed by members of the proggrörelsen (Svensson 2009: 111). During the 1970s, the 'progressive' music movement or proggrörelsen was a considerable force in Swedish popular culture. Much like the nueva canción movement, it was a left wing and anti-capitalist movement that emerged in the late 1960s (Thyrén 2009). Its political engagement included expressing solidarity with those segments of the Chilean population that were prosecuted, killed, repressed, or had fled the country after the military coup. Musicians who were members of the proggrörelsen wrote songs in support of nueva canción musicians in particular, and the Chilean population in general.

The song 'Gracias a la vida' (a thank you to life) that was originally performed by Violetta Parra, one of the most important members of the nueva canción movement, became especially important for the Swedish solidarity movement, as Finnish-Swedish singer and songwriter Arja Saijonmaa covered the song, that, in its Swedish version was called 'Jag vill tacka livet' (I want to thank life), and later performed it at the funeral of Prime Minister Olof Palme on the $15^{\text {th }}$ of March 1986. The song then resurfaces in contemporary Swedish hip-hop culture. It is part of an episode of the Swedish TV show Lyckliga gatan (the 'lucky' or 'happy' Street) that features The Salazar Brothers as producers. The TV station TV4 describes the show as follows:

\begin{tabular}{|l|l|}
\hline $\begin{array}{l}\text { I Lyckliga gatan i TV4 skildras } \\
\text { unika musikaliska möten över } \\
\text { generations- och } \\
\text { genregränserna, för att skapa } \\
\text { nya tolkningar av både }\end{array}$ & $\begin{array}{l}\text { The show Lyckliga gatan on } \\
\text { TV4 describes unique musical } \\
\text { meälkända svenska låtar ur den } \\
\text { and across generations } \\
\text { ar hipho musikskatten och hits } \\
\text { create new interpretations of } \\
\text { both well-known Swedish } \\
\text { songs from the 'Swedish } \\
\text { musical treasure', and hits } \\
\text { from the Hip hop genre. }\end{array}$ \\
\hline
\end{tabular}

In the episode that I focus on here, the Swedish rapper Gee Dixon, who does not have a familial connection to Chile, covers Arja Saijonmaa's song 'Jag vill tacka livet'. The song is introduced as a cover of Violetta Parra's original version, and Salla and Masse from The Salazar Brothers argue that 
while Saijonmaa's version is depressing, the original Chilean version is even more depressing since it is seen in connection to Pinochet's dictatorship (0:28 in the clip). The episode also features two other Swedish rappers whose parents came from Chile to Sweden during the regime: rapper Carlito, and Ulises Infante Azocar, also known as Stor. Carlito and Masse from The Salazar Brothers argue that Swedish-Chilean rappers are 'returning' to Chile by creating a musical connection to nueva canción musicians, whereby they, that is, what Carlito calls the 'second generation' are now 'closing the circle' (1:01). The episode ends with rapper Gee Dixon performing a new version of the song produced by The Salazar Brothers together with Swedish-Chilean rapper Stor.

This definition of a Chilean identity through hip-hop is once more directed at a Swedish, rather than a Chilean context. The artists who are part of this episode of 'Lyckliga gatan' specifically accentuate a connection to their parent's generation that fled from Chile by referring to nueva canción musicians and the proggrörelsen. Thereby, they also stress that certain aspects of Chilean culture continued to exist outside of Chile during the 1970s and 1980s, as it was forbidden to listen to nueva canción music in Chile during the Pinochet regime. The episode thus creates a narrative of belonging in Sweden that is not only based on remembering the solidarity of the 1970s and the atrocities committed by the Pinochet regime. It also represents such a past as an important part of hip-hop culture in Sweden in general.

\section{Conclusion: Narratives of Belonging, Multiculturalism and Hip-hop Culture}

I thus argue that the work of Swedish hip-hop artists who actively address a Chilean background through their work can be read as narratives of belonging in (at least) four ways. Firstly, the artists create a narrative of belonging in Sweden by making visible the experiences of marginalized youth in the racially segregated low-income areas of the förorten in mainstream media. This function of hip-hop has not only been stressed by earlier Swedish research, but has also been described as a central aspect of the genre in the United States where hip-hop has been discussed as representing marginalized, low-income urban areas (Sernhede \& Söderman 2010; Forman 2002; Chang 2006). The second way in which the artists discussed here create a narrative of belonging in Sweden is by connecting this visibility of the förorten to a historical 
narrative of solidarity between Chile and Sweden during the 1970s. This narrative of political and cultural solidarity is nevertheless based on a version of the past that neither takes into account any historical complexities or conflicts within the very heterogeneous Chilean or Latin American exile community, nor between the exile communities and the Swedish solidarity movement in particular and Swedish society in general (Olsson 2007: 220; Bergman forthcoming).

The third way in which these artists create narratives of belonging is by drawing on a Chilean or Latin American identity that is based on an image of the Latin-American migrant that emerged in Sweden during the Chilean exile period, that is, between 1973 and 1990. This assumption is affirmed by the fact that the definition of a Chilean identity as 'cultural' works in a Swedish, yet not in a Chilean context. While there are a number of factors that are important for the creation of such a Chilean artist identity such as familial connections, or the influence of The Latin Kings on groups such as Advance Patrol and Hermanos Bernal, it was mainly created as a reaction to being identified as different in Sweden. This 'cultural' aspect is also related to the fourth way in which the artists create a narrative of belonging through their work, as they not only connect their work to a political, but also to a cultural solidarity movement in Sweden. They create such a connection in order to stress the solidarity between Chile and Sweden during the 1970s as an important part of a specific Chilean identity in particular, and as central for the Swedish hip-hop community in general. Their definition of a Chilean artist identity thus not only works in a Swedish context, it also defines Chileans as a 'special' migrant group in Sweden that, through the prominence of The Latin Kings and The Salazar Brothers has become a dominant force in Swedish hiphop culture.

However, as this article has solely focused on the intersection of a Chilean identity and hip-hop culture in Sweden, there are several issues that have not been mentioned in greater detail. The article for instance, does not discuss the significance of hip-hop in the broader context of a Chilean diaspora. The Swedish hip-hop artists mentioned here work with other artists with a Chilean background in European countries such as Norway, and their music transcends national boundaries. During our interview, Rodde mentioned that Hermanos Bernal have received fan mail from exiled Chileans living in countries such as Austria or Canada. This article also does not consider the issue of the connections between exiled Chilean musicians on the one hand, 


\section{Susan Lindholm}

and artists that remained in or returned to Chile, such as Ana Tijoux on the other ${ }^{3}$.

In conclusion, it must once more be stressed that not all Swedes who have a familial background in Chile choose to connect to such a background in the same way as the artists discussed here. Inevertheless argue that this specific negotiation of a Chilean identity becomes intelligible as a narrative of belonging in Sweden against the background of othering and segregation processes in Sweden, and a form of multiculturalism that affirms both difference and equality. It sets out to create belonging as a reaction to othering processes that are visible in both the persisting segregation in housing and labour markets along ethnic and racial lines, as well as the election of the Sweden Democrats, a right-wing, anti-immigration party into the Swedish national parliament in 2010, 2014, and most recently in 2018. It also creates belonging in the context of a multiculturalism debate that stresses difference as desirable, that is, as a means of inclusion into mainstream society. If being different means being part of a group, individuals will set out to define their specific difference, in this case by creating narratives of belonging that connect them to a specific (idealized) version of a Swedish past, in order to define their membership within that group. Against this background, it would also be interesting to trace the way in which other migrant groups, who cannot claim such a 'special' historical connection within a specific national context, set out to create narratives of (national) belonging. This applies to most refugees who arrived in Sweden as part of what has been called the 'European migrant crisis' beginning in 2015 .

\section{References}

Bade, K.J. 2003. Migration in European History Cambridge, Mass.: Blackwell Publishing.

https://doi.org/10.1002/9780470754658

${ }^{3}$ For a discussion of return movements between the US and Chile and Sweden and Chile, see for instance: Tollefsen Altamirano (2000). For a discussion of the entangled history of hip-hop culture in-between Chile and Sweden, see Lindholm (2016), and finally, for a discussion of belonging and popular culture focusing on the work of Chilean artist Ana Tijoux, see Lindholm (2018). 
Bergman, J. forthcoming. Är deras sak vår? Svensk solidaritet med Chile 19711991.

Brah, A., M.J. Hickman \& M. Mac an Ghaill (eds.) 1999. Thinking Identities: Ethnicity, Racism and Culture. Basingstoke: Macmillan.

https://doi.org/10.1057/9780230375963

Byström, M. \& P. Frohnert (ed.) 2013. Reaching a State of Hope: Refugees, Immigrants and the Swedish Welfare State, 1930-2000. Lund: Nordic Academic Press.

Chang, J. 2006. Can't stop won't stop: hiphop-generations. Historia. 1. svenska utg. Göteborg: Reverb.

Christiaens, K., M. Rodriguez Garcia \& I. Goddeeris (eds.) 2014. European Solidarity with Chile 1970s-1980s. Frankfurt am Main: Peter Lang. https://doi.org/10.3726/978-3-653-04659-5

Esquivel Sánchez, M.D. 2005. 'Yo puedo bien espanol' Influencia sueca y variedades hispanas en la actitud lingüística e identificación de los hispanoamericanos en Suecia, Diss. Umeå: Umeå Universitet.

Ericsson, U., I. Molina \& P-M. Ristilammi 2002. Miljonprogram och media: föreställningar om människor och förorter. Stockholm: Riksantikvarieämbetet.

Forman, M. 2002. The 'hood comes first: Race, Space, and Place in Rap and Hip-hop. Middletown, Conn.: Wesleyan University Press.

Gillis, J.R. 1996. Memory and Identity: The History of a Relationship. In Gillis, J.R. (ed.) Commemorations: The Politics of National Identity. Princeton: Princeton University Press

Gradskova, Y. n.d. 'Vad angår oss Chile? Solidaritetskultur som en emotionell gemenskap' unpublished manuscript.

Hübinette, T. \& C. Lundström 2014. Three Phases of Hegemonic Whiteness: Understanding Racial Temporalities in Sweden. Social Identities: Journal for the Study of Race, Nation and Culture 20,6: 423 - 437.

https://doi.org/10.1080/13504630.2015.1004827

Lilja, E. 1999. Den ifrågasatta förorten: identitet och tillhörighet i moderna förorter. Stockholm: Byggforskningsrådet.

Lindholm, S. 2018. Belonging and Popular Culture - The Work of Chilean Artist Ana Tijoux. InterDisciplines 9:1: 73 - 94.

Lindholm, S. 2016. Remembering Chile: An Entangled History of Hip-hop inbetween Sweden and Chile. Diss. Malmö: Malmö University.

Lindqvist, B. 1991. Drömmar och vardag i exil: om chilenska flyktingars 
kulturella strategier, Diss. Stockholm: Stockholm University.

Modood, T. 2013. Multiculturalism. Oxford: Wiley

Nilsson, M. 2008. Litteratur, etnicitet och föreställningen om det mångkulturella samhället. Samlaren 129: 270 - 304.

Olsson, E. 2007. Bortom exilen - diasporiseingen av chilenare i Sverige. In

Olsson, E. (ed.). Transnationella Rum: diaspora, migration och gränsöverskridande relationer. 1. uppl. Umeå: Boréa.

Puskás, T. 2009. 'We belong to them': Narratives of Belonging, Homeland and

Nationhood in Territorial and Non-territorial Minority Settings. Diss.

Linköping: Linköpings University.

Regeringskansliet 2011. Sveriges företagande och konkurrenskraft. Internationell benchmarking. [Sweden's Business and its Competitiveness. International Benchmarking.] Stockholm: Fritzes.

Ristilammi, P-M. 1994. Rosengård och den svarta poesin: en studie av modern annorlundahet. Diss. Lund: Lund University.

Sernhede, O. 2007. Alienation is My Nation: hiphop och unga mäns utanförskap i Det nya Sverige. [Ny utg.] Stockholm: Ordfront.

Sernhede, O. \& J. Söderman 2010. Planet Hiphop: om hiphop som folkbildning och social moblisering. 1. uppl. Malmö: Liber.

Svensson, A. 2009. El exilio latinoamericano en Suecia: literatura y estudios. In Migrations and Connections: Latin America and Europe in the Modern World: Papers of the Fifty-fourth Annual Meeting of the Seminar on the Acquisition of Latin American Library Materials, Berlin 2009.

Thyrén, D. 2009. 'Inledning'. In Thyrén, D. Musikhus i centrum: två lokala praktiker inom den svenska progressiva musikrörelsen: Uppsala Musikforum och Sprängkullen i Göteborg. Diss. Stockholm: Stockholms Universitet.

Thörn, H. 2002. Globaliseringens dimensioner: nationalstat, världssamhälle, demokrati och sociala rörelser. Stockholm: Atlas.

Tollefsen, A.A. 2000. Seasons of Migrations to the North: A Study of Biographies and Narrative Identities in US-Mexican and SwedishChilean Return Movements. Diss. Umeå: University of Umeå.

Tornbjer, C. 2008. Moralisk chock och solidaritet. 1973 och det Svenska engagemanget för Chile. In Cronqvist, M., L. Sturfelt \& M. Wiklund (ed.): 1973: en träff med tidsandan. Lund: Nordic Academic Press.

Weedon, C. 2004. Identity and Culture: Narratives of Difference and Belonging. Maidenhead: Open University Press. 
Ålund, A. \& C-U Schierup 1991. Prescribed Multiculturalism in Crisis. Paradoxes of Multiculturalism: Essays on Swedish Society. Aldershot: Avebury.

\section{Interviews}

Interview with Rodrigo Rodde Bernal, hip hop artist; recorded by Susan Lindholm, 18 November 2013.

Interview with Cristian Salla Salazar Campos, producer and activist; recorded by Susan Lindholm, 14 July 2015.

\section{Electronic Sources}

Advance Patrol channel 'Advance Patrol - 'Ett land som är trygt'/ 'Betongbarn'. Available at:

https://www.youtube.com/watch?v=J5sOvfV8cnU

(Accessed on 30 June 2016.) https://doi.org/10.18356/b0d43eec-en

Hiphoptexter 'Betongbarn' and 'Ett land som är tryggt'. Available at: http://hiphoptexter.com/ (Accessed on 30 June 2016.)

TV4. Arjas låt större än Gee Dixon någonsin kunnat ana - Lyckliga gatan (TV4). Available at: https://www.youtube.com/watch?v=icL4fYvntSw (Accessed on 26 May 2016.)

TV4. Gee Dixons tolkning av Arja Saijonmaas Jag vill tacka livet - Lyckliga gatan (TV4). Available at:

https://www.youtube.com/watch?v=PxFVNgWEzKM

(Accessed on 26 May 2016.)

Susan Lindholm School of History and Contemporary Studies Södertörn University Sweden susan.lindholm@sh.se 